\title{
PPARG genindeki Pro12Ala polimorfizmi, Türk populasyonunda insülin direnci ve tip 2 diyabet ile ilişsili değildir: Bir vaka-kontrol çalışması
}

\section{Pro12Ala polymorphism in the PPARG gene is not associated with the development of insullin resistance and type 2 diabetes in the Turkish population: A case-control study}

iD Dudu Erkoç-Kaya ${ }^{1}$ (iD Hilal Arıkoğlu1, iD Funda İşçioğlu², iD Süleyman Hilmi İpekçi³, iD Süleyman Baldane ${ }^{4}$

${ }^{1}$ Selçuk Üniversitesi, Tıp Fakültesi, Tıbbi Biyoloji AD, Konya, Türkiye

${ }^{2}$ Ege Üniversitesi, Fen Fakültesi, İstatistik AD, İzmir, Türkiye

${ }^{3}$ İstanbul Atlas Üniversitesi, Sağlık Bilimleri Fakültesi, Beslenme ve Diyetetik Bölümü, İstanbul, Türkiye

${ }^{4}$ Selçuk Üniversitesi, Tıp Fakültesi, Endokrinoloji BD, Konya, Türkiye

$\ddot{O} z$

Amaç: Tip 2 diyabet (T2D), diyabetin en sık görülen türüdür ve tüm dünyada olduğu gibi ülkemizde de ciddi bir halk sağlığ1 sorunu haline gelmiştir. İnsülin sekresyonunun azalması ve/veya insülin direnci (IR) gelişimi, T2D patogenezinde yer alan iki ana bozukluktur. Kromozom 3p25'te yer alan peroksizom proliferatör aktive reseptör gama (PPARG) geni tarafindan kodlanan ve esas olarak adipositlerde eksprese edilen PPARG2, glikoz ve lipid metabolizmasının düzenlenmesinde yer alan çok sayıda anahtar geni düzenler. Fonksiyonel önemi dolayısıyla, T2D gelişimi ile ilişkisi ilk rapor edilen aday gen PPARG2 (Pro12Ala varyantı)'dir. Calıșmamızda, PPARG genindeki Pro12Ala'nın IR gelișimi ve T2D riski üzerine etkilerini Konya bölgesinde yaşayan 387 (181 non-obez/ 206 obez) T2D ve 264 (137 non-obez/127 obez) sağlıklı birey olmak üzere toplam 650 kişide değerlendirmeyi amaçladık.

Yöntem: Bireylerden alınan kan örneklerinden, T2D ilişkili biyokimyasal parametreler analiz edildi ve sonrasında HOMA-IR (HOMA indeksi) hesaplandı. HOMA-IR indeksi $2.5^{\prime}$ ten yüksek olan kişiler insüline dirençli olarak kabul edildi. İzole edilen DNA örneklerinde, Pro12Ala genotiplendirmesi RT-PCR tekniği ile yapıldı. İstatistiksel analiz için SPSS18.0 programı kullanıldı. $\mathrm{P}<0.05$ istatistiksel olarak anlamlı kabul edildi.

Bulgular: Obez hasta grubu dışında diğer hasta ve kontrol grupları Hardy-Weinberg dengesinde değildi ( $<<0.05)$. Dominant, resesif ve additif modeller kurularak yapılan ilişkilendirme analizine göre Pro12Ala polimorfizminin T2D riski ve ilişkili biyokimyasal parametreler üzerine bir etkisi bulunmadı ( $\mathrm{p}>0.05$ ).

Sonuç: Hastalığın poligenik doğası ve çevresel faktörlerin karmaşıklığı, genlerin T2D patogenezindeki etkisinin anlaşılmasını zorlaştırmaktadır. Bu nedenle, PPARG'nin hastalığın genetik zeminindeki olası rolünü ortaya çıkarmak için daha büyük popülasyonlarda daha fazla çalışmaya ihtiyaç vardır. Çalışma Türk toplumunda PPARG ve T2D ilişkisi bakımından sunulan ilk rapordur.

Anahtar Kelimeler: Tip 2 diyabet, PPARG, Pro12Ala, Türk populasyonu

Abstract

Objective: Type 2 diabetes (T2D) is the most common type of diabetes and has become a serious public health problem in our country as worldwide. Reduction of insulin secretion and/or insulin resistance (IR) development are two major defects in T2D pathogenesis. PPARG2, which is encoded by the peroxisome proliferator activated receptor gamma (PPARG) gene, located chromosome 3p25, is mainly expressed in adipocytes and regulates a large number of key genes involved in regulation of glucose and lipid metabolism. The first reported candidate gene associated with T2D is PPARG2 (Pro12Ala variant), due to its functional importance. We aimed to evaluate the effects of Pro12Ala on IR development and T2D risk in 650 individuals, which of 387 (181 non-obese/ 206 obese) individuals with T2D and 264 (137 non-obese/127 obese) healthy individuals in Konya region.

Method: T2D-related biochemical parameters were analyzed from blood samples and HOMA-IR (HOMA index) was calculated. Individuals with a HOMAIR index higher than 2.5 were considered resistant to insulin. Pro12Ala genotyping was performed by RT-PCR technique in DNA samples isolated from lymphocytes. $\mathrm{P}<0.05$ was considered statistically significant.

Results: Patient and control groups except Obese patient group were not in Hardy-Weinberg equilibrium ( $<0.05)$. Pro12Ala polymorphism had no effect on T2D risk and biochemical parameters according to association analysis under dominant, recessive, additive models ( $>0.05$ ).

Conclusion: Consequently, the Pro12Ala in PPARG gene was not associated with T2D and biochemical phenotypes in the Turkish population. The polygenic nature of the disease and complexity of environmental factors makes it difficult to understand the effect of the genes in the pathogenesis of T2D. Further studies in larger populations are needed to reveal the possible role of PPARG in the genetic background of the disease. The study is the first report of PPARG and T2D association in Turkish population.

Keywords: Type 2 diabetes, PPARG, Pro12Ala, Turkish population

Yazışma Adresi: Dudu Erkoç-Kaya, Selçuk Üniversitesi, Tıp Fakültesi, Tıbbi Biyoloji AD, Konya, Türkiye

E-Posta: dudu erkoc@hotmail.com

Alınma tarihi: 01.11.2021 / Kabul tarihi: 20.12.2021 / Yayımlanma tarihi: 15.12.2021

Türklerde obez ve non-obez Tip 2 diyabet ve PPARG ilişkisi - Erkoç-

Genel Tip Derg 2021;31(4)339-343

Kaya ve ark. 
Tip 2 Diyabet (T2D) en s1k görülen diyabet tipidir ve salgın bir hastalık gibi insanların yaşam kalitelerini bozması, gelişen ciddi komplikasyonları ve tedavisinin ekonomiye getirdiği yük nedeniyle tüm dünyada olduğu gibi ülkemizde de ciddi bir halk sağlığ 1 sorunu haline gelmiştir. T2D patogenezinde; insülin salınımının azalması ve hedef dokularda (kas, yağ vb) insüline duyarlılığın azalması sonucu insülin direnci gelişimi veya her ikisinde birden ortaya çıkan bozukluk yer alır. Bu iki temel bozukluğun ortaya çıkışında genetik faktörlerin etkili olduğu biliniyor olmasına rağmen, genetik zeminin anlaşılmasına yönelik yapılan yoğun çalışmalarda elde edilen bilgiler genetik temelin tam olarak açıklanabilmesi için hala yeterli değildir. Yakın zamana kadar; yaklaşık 45 lokus Avrupa populasyonunda ve 29 lokus Asya populasyonunda (özellikle doğu ve güney Asya) olmak üzere 70 civarında gen lokusu tip 2 diyabetle ilişkilendirilmiştir $\left(\mathrm{p}<5 \times 10^{-8}\right)$ [1]. Peroksizom proliferatör-aktive edici reseptör gamma (PPARG) geni; adiposit gelişimi ve fonksiyonunda anahtar rol oynayan lipid ile aktive olan nukleer hormon reseptör süper ailesine ait transkripsiyon faktörlerinden PPAR $\gamma$ ' yı kodlar. PPAR $\gamma$ yapısal olarak çekirdekte lokalizedir, retinoid X reseptörü (RXR) ile heterodimerize olur ve ko-reseptörlerine bağlanır. Ligand bağlanmasıyla reseptörde konformasyonel değişiklik olur ve bu değişim korepresör kompleksinin ayrışmasını tetikleyerek koaktivatör proteinlerin bir araya gelmesi ve gen ekspresyonunun aktivasyonu ile sonuçlanır [2-4]. PPARG geni, kromozom 3p25'de yerleşiktir. 9 ekzonu bulunan genin farklı promotor kullanımı ve alternatif kesim sonucu oluşturduğu; PPARG1, PPARG2, PPARG3 ve PPARG4 olmak üzere dört kesim varyantı bulunur. Ancak bu farklı sayıdaki PPARG transkriptlerine rağmen, PPARG1, PPARG3 ve PPARG4 varyantları tarafindan kodlanan aynı protein olan PPAR $\gamma 1$ ve PPARG2 varyantının kodladığ N-terminalinde 28 ilave aminoasitli bir protein olan PPAR $\gamma 2$ olmak üzere sadece iki protein izoformu üretilir. PPAR $\gamma 1$; yağ dokusu, kalp, karaciğer ve iskelet kası gibi çok sayıda doku ve hücre tipinde orta düzeyde ifade edilirken PPAR $\gamma 2$ temel olarak adipositlerde ifade edilir ve burada yağ hücrelerinin farklılaşmasındaki başlıca düzenleyicidir [5-7]. Tip 2 diyabet hastalarında hiperglisemi tedavisi için kullanılan troglizatone, pioglitazone, rosiglitazone gibi Thiazolidinedoin sınıfı insülin duyarlılığını artıran ilaçların da hedefi olan PPAR $\gamma 2$ glukoz ve lipid metabolizmasının düzenlenmesinde iş gören ve adiposit gelişimi ve işlevinde önemli rol oynayan çok sayıda anahtar genin transkripsiyonunu düzenler [8-11]. Aday gen çalışmalarında elde edilen ilk önemli sonuç, genin PPAR $\gamma 2$ transkriptinde yer alan ve ekzon 2 bölgesinde yerleşik Pro12Ala (P12A) varyantının 1997 yılında ilk kez tip 2 diyabet ile ilişkilendirilmesidir [12 ]. Bu varyant, sonraki yıllarda da farklı populasyon ve etnik gruplarda gerçekleştirilen çalışmalar ve meta analizlerde tutarlı bir biçimde insülin direnci ve T2D ile ilişkilendirilmiştir [13-15].

Yapılan literatür taramasına göre; birçok populasyonda, PPARG geni ve T2D gelişiminin araştırıldığ çalışma bulunmasına rağmen Türk populasyonda bu ilişkinin analiz edildiği bir rapora rastlanmamıştır. Buradan yola çıkarak çalışmamızda; Konya bölgesinde yaşayan obez ve obez olmayan diyabetik ve sağlıklı bireylerden oluşan Türk populasyonunda PPAR $\gamma 2$ genindeki Pro12Ala (rs1801282) polimorfizminin insülin direnci gelişimi ve T2D riski üzerine etkilerinin araştırılması amaçlanmıştır.

\section{Çalıșma gruplarının olușturulması ve klinik özellikler}

Çalışmaya, S.Ü. İç Hastalıkları AD Endokrinoloji Bilim Dalında, ADA (American Diabetes Association) kriterlerine göre T2D tanıs1 konmuş 387 (181 non-obez/206 obez) birey ile yaş/vücut kitle indeksi eşleştirilmiş 264 (137 non-obez/127 obez) sağllklı birey olmak üzere toplam 650 birey alınd1.

T2D'li bireylerin çalışmaya dahil edilmesinde, T2D ADA kriterleri yanı sıra, hasta kişilerin insülin kullanmıyor olmaları, 30 yaş üstü bireyler olmaları, herhangi bir birinci dereceden akrabanın planlanan çalışmamıza dahil edilmemiş olması aranan major şartlardı. Bilinen diğer diyabet tipleri (tip 1 diyabet, MODY, LADA, ilaca bağlı ve diğer tipler) daha sağlıklı değerlendirme adına dışlandı. Obezite durumu vücut kitle indeksleri (VKI) hesaplanarak belirlendi, VKI $\geq 30$ olan bireyler obez, $\mathrm{VKI}<30$ olan bireyler ise obez olmayan gruplara kayıt edildi. Kontrol grubu, herhangi bir metabolik hastalığı olmayan, birinci derece akrabasında diyabet hikayesi bulundurmayan ve 30 yaş üzeri sağlıklı bireylerden seçildi. Pre-diyabet şüphesi bulunan bireyler Oral Glukoz Tolerans Testi (OGTT) uygulanarak tekrar değerlendirildi. İnsülin direnci ve ya bozulmuş glukoz toleransı olduğu belirlenen kişiler çalışma kapsamına alınmadılar.

Kişilerin antropometrik bilgileri kayıt edilerek, biyokimyasal analizler kapsamında açlık kan glukoz, insülin, c-peptid, HbA1c, kolesterol, HDL, LDL, trigliserid düzeyleri ölçüldü. İnsülin direnci varlığı; HOMA-IR (Homeostasis Model Assesment of Insulin Resistance) hesaplaması ile değerlendirildi. Bunun için, açlık insülin $(\mu \mathrm{IU} / \mathrm{ml})$ $\mathrm{x}$ açlık glukoz $(\mathrm{mmol} / \mathrm{ml}) / 22,5$ formülü kullanıldı ve 2,5 üzerinde değerlere sahip kişiler insüline dirençli kabul edilerek çalışma kapsamından çıkarıldı.

Genotiplendirme yapmak için kullanılmak üzere DNA izolasyonu için her bir kişiden 5-6 cc periferik kan alınarak EDTA'lı tüplere koyuldu. Seçilen gönüllülere çalışma ile ilgili olarak önceden bilgilendirme yapıldı ve onamları alınarak çalışma sürdürüldü. Bu çalışma Selçuk Üniversitesi Tip Fakültesi Etik Kurulu tarafindan onaylandı (Karar Sayı No: 2013/305 Konya, Türkiye).

\section{DNA izolasyonu ve Genotiplendirme}

Bireylerden alınan kandan genomik DNA izolasyonu, standart proteinaz K ve SDS prosedürü kullanılarak gerçekleștirildi. PPARG nükleotid dizisi GenBank database'den elde edildi. PPARG genindeki Pro12Ala polimorfizminin genotiplendirilmesi gerçek zamanlı polimeraz zincir reaksiyonu (Real Time-PZR) tekniği ile yapıldı. Real-time PZR tekniğinde, floresan primer ve prob kullanılarak hedeflenen bölgelerin amplifikasyonu ile eş zamanlı olarak hedef SNP belirlendi. Reaksiyon karışımı; FastStart Taq DNA polimeraz, reaksiyon tamponu, $\mathrm{MgCl}_{2}$ ve dNTP den oluşan master mix, su ve biri yaygın allele diğeri ise nadir allele özgün tasarlanan 2 adet primerprob kullanılarak hazırlanmıştır. Gerçek zamanlı PCR protokolü; $95{ }^{\circ} \mathrm{C}$ de $10 \mathrm{dk}$ preinkübasyon, $95^{\circ} \mathrm{C}$ de 10 sn denatürasyon, $59{ }^{\circ} \mathrm{C}$ de 10 sn bağlanma, $72{ }^{\circ} \mathrm{C}$ de 15 sn uzama adımlarından oluşan 40 amplifikasyon döngüsü; $95^{\circ} \mathrm{C}$ de $30 \mathrm{sn}, 40^{\circ} \mathrm{C}$ de $2 \mathrm{dk}, 75^{\circ} \mathrm{C}$ de $1 \mathrm{sn} 1$ döngü ve $40^{\circ} \mathrm{C}$ de 30 sn 1 döngü soğutma olacak şekilde programlandı. 
Klinik ve biyokimyasal özellikler, tanımlayıcı istatistikler yapılarak değerlendirildi. Normal dağılımlı parametreler tek yönlü varyans analizi (ANOVA) kullanılarak, normal dağılım göstermeyen parametreler ise dönüşüm sonrası Kruskal-Wallis testi ile karşılaştırıldı. SNP genotiplerinin hasta ve kontrol gruplarındaki dağılımı ve grupların Hardy-Weinberg (HW) dengesizliği bakımından değerlendirilmelerinde ki-kare testi kullanıldı. Klinik ve biyokimyasal analizler için gerçekleştirilen tanımlayıcı istatistik analizlerinde, parametreler ortalama \pm standart sapma şeklinde gösterildi. İstatistiksel analizler SPSS18 programı kullanılarak gerçekleştirildi. $\mathrm{P}<0.05$ istatistiki olarak anlamlı kabul edildi.

\section{İlişki analizleri}

Pro12Ala genotipinin diyabet ile ilişki analizi lojistik regresyon ile değerlendirildi. Hasta ve kontrol gruplarında hedef SNP Pro12Ala frekansları Odds oranları hesaplanarak belirlendi. İlişki analizleri için dominant, additif (kodominant) ve resesif modeller kuruldu. Modeller allel 2 (nadir allel) dikkate alınarak kuruldu. Dominant model analizinde allel 2 taşıyan genotipler (homozigot allel 2 ve heterozigot), homozigot allel 1 taşıyan genotip ile karş1laştırılırken, resesif kurulan modelde; homozigot allel 2 genotipi, allel 1 taşıyan genotiplerle (homozigot allel 1 ve heterozigot) karşılaştırma yapıldı. Lojistik regresyon analizi, sadece SNP genotiplerinin dominant, aditif ve resesif modellerini değil, aynı zamanda cinsiyet ve yaşı da dikkate alarak yapıldı.

PPARG genotipleri ve T2D'nin karakteristik biyokimyasal özellikleri arasında herhangi bir ilişki olup olmadığı araştırıldı. Öncelikle, biyokimyasal parametrelerin normallik varsayımı testleri yapıldı. Açlık plazma insülini, TG ve Kol değişkenleri, ANOVA analizinden önce log transformasyonu ile normalize edildi. AKŞ, HOMA-IR ve diğer özellikler (BKI, c-peptid, HbA1C, LDL, HDL) için KruskalWallis testi yapıldı. SNP genotipleri 11, 12 ve 22 olarak kodlandi.

\section{Bulgular}

\section{Çalışma gruplarının klinik ve biyokimyasal özellikleri}

Hasta ve kontrol gruplarının klinik özellikleri karşılaştırıldığında açlık kan şekeri ve HOMA-IR değerleri bakımından önemli farklılık gözlenirken açlık insülin açısından önemli bir farklılık gözlenmedi. Hasta ve kontrol grupları obez ve non obez olarak karşılaştırıldı ğında ise; açlık kan şekerinde farklılık bulunmazken açlık insülin ve HOMA-IR bakımından önemli farklılık olduğu tespit edildi $(\mathrm{p}<0.05)$. (Tablo 1)

\section{Pro12Ala'nın T2D ve fentotipler ile ilişkisi}

Çalışma gruplarında Pro12Ala varyantı için tespit edilen allel frekansları Tablo 2'de verilmiştir. Genotip dağılımları bakımından değerlendirildiğinde obez hasta grubu dışında diğer hasta ve kontrol grupları Hardy-Weinberg dengesinde değildi $(\mathrm{p}<0.05)$. PPARG geni Pro12Ala değişimi, hem çalışmaya dahil edilen tüm bireyler birlikte hasta ve kontrol olarak hem de obez ve non-obez gruplar şeklinde ayrılıp kendi içlerinde hastalıkla ilişkisi bakımından analiz edildi. Dominant, resesif ve additif modeller kurularak yapılan ilişki analizinde Pro12Ala değişiminin her üç karşılaştırmada da T2D riski ile ilişkili olmadığ ve biyokimyasal fenotipler üzerine herhangi bir etkisinin olmadığ 1 tespit edildi ( $\mathrm{p}>0.05$ ) (Tablo 3). SNP genotiplerinin

Tablo 1. Çalışmaya dahil edilen bireylerin klinik ve biyokimyasal özellikleri

\begin{tabular}{|c|c|c|c|c|c|c|c|c|}
\hline & \multicolumn{2}{|c|}{ OBEZ } & \multicolumn{2}{|c|}{ NON-OBEZ } & \multicolumn{4}{|c|}{$P$} \\
\hline & $\begin{array}{l}\text { DM } \\
\text { (1) }\end{array}$ & $\begin{array}{c}\text { Kontrol } \\
\text { (2) }\end{array}$ & $\begin{array}{l}\text { DM } \\
\text { (3) }\end{array}$ & $\begin{array}{c}\text { Kontrol } \\
\text { (4) }\end{array}$ & $p(1-2)$ & $p(1-3)$ & $p(2-4)$ & $p(3-4)$ \\
\hline Sayı & 206 & 127 & 181 & 137 & $\mathrm{NA}$ & $\mathrm{NA}$ & NA & $\mathrm{NA}$ \\
\hline $\mathbf{K} / \mathbf{E}$ & $153 / 51$ & $107 / 20$ & $69 / 112$ & $66 / 71$ & $\mathrm{NA}$ & $\mathrm{NA}$ & $\mathrm{NA}$ & $\mathrm{NA}$ \\
\hline Yaş (yll) & $55.3 \pm 8.9$ & $49.2 \pm 11.5$ & $56.3 \pm 9.3$ & $41.9 \pm 9.7$ & $<0.001 *$ & 0.675 & $<0.001 *$ & $<0.000^{*}$ \\
\hline VKİ (kg/m²) & $35.86 \pm 6.03$ & $34.65 \pm 3.96$ & $26.74 \pm 2.39$ & $26.57 \pm 3.85$ & 0.105 & $\mathrm{NA}$ & $\mathrm{NA}$ & 0.09 \\
\hline İnsülin' ${ }^{1}(\mu \mathrm{IU} / \mathrm{ml})$ & $12.28(2.04-54.98)$ & $10.85(2.86-73.82)$ & $8.4(7.68-9.01)$ & $7.16(6.58-7.56)$ & 0.172 & $<0.000^{*}$ & $<0.000^{*}$ & $0.001 *$ \\
\hline $\mathbf{A K S ^ { 1 }}(\mathbf{m g} / \mathbf{d l})$ & $139(64-377)$ & $94.5(76-113)$ & $135(59-526)$ & 91 (58-124) & $<0.001 *$ & 0.706 & $<0.085$ & $<0.001 *$ \\
\hline HОМА-IR ${ }^{1}$ & $4.45(0.41-27.42)$ & $2.63(0.69-18.41)$ & $2.81(0.05-23.57)$ & $1.61(0.40-19.71)$ & $<0.001 *$ & $<0.000^{*}$ & $<0.000^{*}$ & $<0.001^{*}$ \\
\hline
\end{tabular}

${ }^{1}$ : normal dağılmayan parametreler, ortanca (min-maks) şeklinde gösterildi.

*: İstatistiki olarak anlamlı farklılı saptand1.

NA: Bu veriler için klinik olarak anlamsız bulunduğu için istatistiki anlamlılık değerlendirilmedi.

DM: Diabetes Mellitus, VKİ: Vücut Kitle İndeksi, AKŞ: Açlık Kan Şekeri, HOMA-IR: Homeostasis Model Assesment of Insulin Resistance 
dominant, additif ve resesif modeller altında hastalıkla ilişkisinin analiz edilmesinin yanı sıra, cinsiyet ve yaş faktörleri de lojistik regresyon ile değerlendirildi. Non-obez grupta cinsiyet hastalık gelişiminde etkili bulunmazken, yaş faktörünün hastalık gelişiminde etkili olduğu tespit edildi (OR: 0.84 [CI: 0.81-0.87], P: 0,000). Obez grupta yapılan değerlendirmede kadın cinsiyet (OR: 2,02 [CI: 1.063.87], P: 0,033) ve yaş (OR: 0,94 [CI: 0.91-0.96], P: 0,000) hastalıkla ilişkili bulundu.

Tablo 2. Çalışma gruplarında PPARG genindeki Pro12Ala allel frekansı

\begin{tabular}{|c|c|c|c|c|c|}
\hline \multirow{2}{*}{ Grup } & \multirow{2}{*}{$\begin{array}{l}\text { Hastalkk } \\
\text { durumu }\end{array}$} & \multicolumn{3}{|c|}{ Genotip / n (\%) } & \multirow{2}{*}{$\begin{array}{c}\mathbf{P} \text { değer } \\
\left(\mathbf{X}^{2}\right)\end{array}$} \\
\hline & & $\mathrm{CC}$ & CG & GG & \\
\hline \multirow{2}{*}{ Non- Obez } & DM & $\begin{array}{c}145 \\
(8011)\end{array}$ & $29(16.02)$ & $7(3.87)$ & \multirow{2}{*}{0.134} \\
\hline & Kontrol & $\begin{array}{c}118 \\
(87.41)\end{array}$ & $14(10.37)$ & $3(2.22)$ & \\
\hline \multirow[t]{2}{*}{ Obez } & DM & $\begin{array}{c}163 \\
(79.12)\end{array}$ & $41(19.91)$ & $2(0.97)$ & \multirow[t]{2}{*}{0.240} \\
\hline & Kontrol & $104(83.2)$ & $17(13.6)$ & $4(3.2)$ & \\
\hline \multirow{2}{*}{$\begin{array}{l}\text { Tüm } \\
\text { çalsıma } \\
\text { grubu }\end{array}$} & DM & $\begin{array}{c}308 \\
(79.59)\end{array}$ & $70(10.08)$ & $9(2.32)$ & \multirow{2}{*}{0.145} \\
\hline & Kontrol & $\begin{array}{c}222 \\
(85.38)\end{array}$ & $31(11.92)$ & $7(2.69)$ & \\
\hline
\end{tabular}

Tablo 3. PPARG genindeki Pro12Ala ve T2D ilişki analizi sonuçları

\begin{tabular}{|l|l|c|c|}
\hline \multirow{4}{*}{ Grup } & \multicolumn{1}{c|}{$\begin{array}{c}\text { Lojistik regresyon } \\
\text { Illiski modeli }\end{array}$} & Odds oranı & P değeri \\
\hline \multirow{4}{*}{ Tüm çalışma Grubu } & CG vs GG & 0.591 & 0.393 \\
\cline { 2 - 4 } & CG+GG vs CC & 0.731 & 0.204 \\
\cline { 2 - 4 } & CG+CC vs GG & 0.827 & 0.739 \\
\hline \multirow{4}{*}{ Non-Obez } & CG vs GG & 1.004 & 0.997 \\
\cline { 2 - 4 } & CG+GG vs CC & 1.985 & 0.108 \\
\cline { 2 - 4 } & CG+CC vs GG & 0.549 & 0.511 \\
\hline \multirow{3}{*}{ Obez } & CG vs GG & 0.253 & 0.149 \\
\cline { 2 - 4 } & CG+GG vs CC & 1.169 & 0.618 \\
\cline { 2 - 4 } & CG+CC vs GG & 3.066 & 0.220 \\
\hline
\end{tabular}

\section{Tartışma}

DNA molekülünde ortaya çıkan ve genellikle de tek nükleotid polimorfizmi (single nucleotide polymorphism; SNP) şeklinde rastlanan polimorfizmlerin ya da varyasyonların önemli bir kısmı işlevsel olmamakla birlikte, bu SNP'lerin bazıları genlerin biyolojik fonksiyonlarını değiştirerek ilgili protein yapısında değişikliğe sebep olabilmekte bazıları da genlerin düzenleyici bölgelerinde bulunarak protein yapı ve işlevini değiştirmese de gen ifadesinde değişime sebep olarak etkili olabilmektedir. Bunların dışında genlerin intronik bölgelerinde yerleşik olan SNP'ler de mRNA işlenmesinde önemli olan intron kesip-ekleme noktalarında kaymalara neden olabilmektedir. Günümüze kadar; aday gen çalışmaları ve genom boyu ilişki çalışmaları ile öne çıkan birçok gen ve genlerde yer alan polimorfizmler, Tip 2 diyabet, obezite ve bunlarla ilişkili fenotipik özellikler ile ilişkili olarak rapor edilmişlerdir [16].

Obezite ve T2D'nin en önemli ortak karakteristik özelliği insüline karşı hedef hücrelerinin gösterdiği dirençtir. Çalışmamızda, tanımlayıcı istatistik analiz sonuçları ile birlikte değerlendirildiğinde, insülin düzeylerinin obez olan diyabetik kişilerde, non-obez diyabetik kişilere göre daha yüksek olması, obezite varlığının insülin direncini artırdığı ve bu durumun hipergliseminin üstesinden gelmek için insülin yapımının artmış olmasından kaynaklandığ 1 şeklinde yorumlanabilir. İnsülin direnci göstergesi olan HOMAIR bakımından değerlendirdiğimizde de, bu değer bütün gruplarda artmış olmasına rağmen obez diyabetiklerle non-obez diyabetikler arasındaki farkın belirgin olması, obezite varlığının insülin direncini artırdığı yorumunu desteklemektedir. İnsülinin hedef dokularda aktivasyon gösterebilmesi için öncelikle reseptörüne bağlanması ve ardından uyarı-ileti yolaklarının aktive olması gereklidir. İnsülinin hedef hücrelerdeki uyarı-ileti sisteminde doğrudan rol alan proteinleri kodlayan genlerin insülin direnci gelişimi üzerindeki etkileri daha net ortaya konulabilmektedir. Ancak, Genom boyu ilişki (GWA) çalışmaları sonucunda, insülin direnci ile güçlü ilişkili bulunduğundan T2D için risk teşkil eden birçok aday gen bildirilmesine rağmen, bu genlerin hangi mekanizmalar yoluyla hastalıkla ilişkili oldukları henüz tam olarak bilinmemektedir [17]. PPAR $\gamma^{\prime}$ nın biyolojik aktiviteleri oldukça geniştir fakat adipositlerde yüksek oranda eksprese edildiğinden ve lipid sentezi ve depolanmasında, insülin sinyallemesinde ve adipokin üretiminde iş gören birçok adiposit spesifik genin ekspresyonunu kontrol ettiğinden, genellikle lipid ve glukoz metabolizmasının transkripsiyonel düzenleyicisi olarak kabul edilir $[18,19]$. Bu öneminden dolayı, gende yer alan polimorfizmlerin şiddetli insülin direnci ve Tip 2 diyabet gelişimine neden olduğu düşünülmektedir. PPARG geninde en çok çalış1lan SNP olan Pro12Ala varyant1, ekzon 2 de lokalize olup PPAR $\gamma 2$ izoformunda bulunur. Bu varyant 1997 yılında ilk kez aday gen çalışmalarında Tip 2 diyabet ile ilişkilendirilmiştir [12]. 2007 ve 2008 yıllarında gerçekleştirilen GWA çalışmalarında da T2D ile ilişkisi teyit edilen birkaç genden biri de yine PPARG geni (P12A varyant1)'dir [20-22]. PPARG'nın Tip 2 diyabet ile ilişkisine yönelik daha önceleri de çalışmalar yapılmış ancak hastalık bakımından koruyucu [14, 23-26], risk faktörü [27-30] ya da herhangi bir ilişkisinin olmadığı [31-35] gibi farklı populasyonlarda farklı sonuçlar rapor edilmiştir. Bizim çalışmamızda, Tip 2 diyabet ile PPARG genindeki Pro12Ala polimorfizmi arasında herhangi bir ilişki tespit edilmemiştir. PPARG, T2D ile ilişkilendirilmesinin yanı sıra troglitazone, rosiglitazone, and pioglitazone gibi tiazolidindion sınıfı insülin-duyarlılığını artıran ilaçların hedefi olarak da bilindiğinden (36) gen ve Pro12Ala varyantı T2D klinik yönetiminde gerek risk skorlama çalışmalarında gerekse ilaç tedavisinde dikkate alınmaktadır [37, 38]. Tiazolidindionların hedefi olmasından kaynaklanan fonksiyonel önemi ve ilişki çalışmalarında elde edilen sonuçlar dikkate alındığında, PPARG geni ve Pro12Ala varyantı diyabet riski bakımından hala çekici bir genetik hedef olmasına [37] rağmen Türk populasyonunda yaptığımız bu çalışmada hastalık ile ve T2D fenotipleriyle ilişkili bulunmamıştır. T2D'nin poligenik bir hastalık olması, çevresel risk faktörlerinin karmaşıklı̆̆ ve kontrolünün güçlüğü ayrıca gen-gen ve gen-çevre etkileşimlerinin (yani diyet, egzersiz ve hastalığın başlangıç yaşı gibi) belirli bir SNP'nin ortaya çıkan fenotipe katkısını büyük ölçüde etkileyebiliyor olması [39], patogenezinde etkili olan genlerin işlevinin anlaşılmasını oldukça zorlaştırmaktadır. Hepsi birlikte değerlendirildiğinde, PPARG varyantları ve T2D ilişkisi bakımından farklı popülasyonlarda elde 
edilen çelişkili sonuçlar biraz daha anlaşılır olmaktadır. Bu nedenle biyolojik işlevinden dolayı ilişkili olması muhtemel olan PPARG geninin hastalığın genetik temelindeki yerini ortaya koyabilmek için daha büyük populasyonlarda yapılacak ileriki çalışmalara ihtiyaç vardir.

Bu çalışmalar; T2D patogenezinin aydınlatılması, diyabet ve ilişkili komplikasyonların gelişimi bakımından risk taşıyan bireylerin belirlenmesi ve genom-ilaç etkileşimlerinin tespit edilmesi yoluyla toplumsal ve/veya bireysel farkl1lıklar gözetilerek hastaların daha etkin bir şekilde tedavi edilebilmesi için önemli bilgiler sağlayabilecek olması açısından önemlidir. Ayrıca toplumlar arasında farklılıkların olduğu, risk gen ve varyantların farklı olabileceği de bilinmektedir. $\mathrm{Bu}$ yüzden toplumlar arasındaki farklılıkların veya benzerliklerin ortaya konması da hastalığın yönetiminde önemlidir.

\section{Teșekkür}

$\mathrm{Bu}$ çalışma, TÜBİTAK tarafından desteklenen kapsamlı araştırma projesinin bir parçasıdır (213S035).

\section{Kaynaklar}

1. Sun X, Yu W, Hu C. Genetics of Type 2 Diabetes: Insights into the Pathogenesis and Its Clinical Application. BioMed Research International 2014;926713. doi:10.1155/2014/926713.

2. Glass CK and Ogawa S. Combinatorial roles of nuclear receptors in inflammation and immunity, Nature Reviews Immunology. 2006;6(1):44-55.

3. Mangelsdorf DJ and Evans RM. The RXR heterodimers andorphan receptors, Cell. 1995;83(6):841-850.

4. Perissi V and Rosenfeld MG. Controlling nuclear receptors: the circular logic of cofactor cycles. Nature Reviews Molecular Cell Biology. 2005;6(7):542-554.

5. Tontonoz P and Spiegelman BM. Fat and beyond: the diverse biology of PPAR $\gamma$. Annu Rev Biochem. 2008;77:289-312.

6. Knouff $\mathrm{C}$ and Auwerx J. Peroxisome proliferator-activated receptor- $\square$ calls for activation in moderation: lessons from genetics and pharmacology. Endoc Rev. 2004;25(6):899-918.

7. Fajas L, Auboeuf D, Raspe E, et al. The organization, ' promoter analysis, and expression of the human PPAR $\square$ gene. Journal of Biological Chemistry. 1997;272(30):18779-18789.

8. Ahmadian M, Suh JM, Hah N, et al. PPAR $\square$ signaling and metabolism: the good, the bad and the future, Nature Medicine. 2013;19:557-566.

9. Bragt MC and Popeijus HE. Peroxisome proliferatoractivated receptors and the metabolic syndrome. Physiology and Behavior. 2008;94(2):187-197.

10. Rosen ED and Spiegelman BM. PPAR $\square$ : a nuclear regulator of metabolism, differentiation, and cell growth. Journal of Biological Chemistry. 2001;276(41):3773137734 .

11. Ahmed W, Ziouzenkova O, Brown J, et al. PPARs and their metabolic modulation: new mechanisms for transcriptional regulation? Journal of Internal Medicine. 2007;262(2):184-198.

12. Yen CJ, Beamer BA, Negri C, et al. 1997. Molecular scanning of the human Peroxisome proliferator activated receptor $\gamma(\mathrm{hPPAR} \gamma)$ gene in diabetic Caucasians: identification of a Pro12Ala PPAR $\gamma 2$ missense mutation. Biochem Biophys Res Commun. 1997;241:270-274.

13. Deeb SS, Fajas L, Nemoto M, et al. A Pro12Ala substitution in PPAR $\gamma 2$ associated with decreased receptor activity, lower body mass index and improved insulin sensitivity. Nat Genet. 1998;20:284-287.

14. Altshuler D, Hirschhorn JN, Klannemark M, et al. 2000. The common PPAR Pro12Ala polymorphism is associated with decreased risk of type 2 diabetes. Nat Genet 2000;26:76-80.

15. Vergotine Z, Yako YY, Kengne AP, et al. T. E. Proliferator-activated receptor gamma Pro12Ala interacts with the insulin receptor substrate 1 Gly972Arg and increase the risk of insulin resistance and diabetes in the mixed ancestry population from South Africa. BMC Genet. 2014 Jan 21;15:10.

16. Lyon HN, Hirschorn JN. Genetics of common forms of obesity: A brief overview. Am
J Clin Nutr. 2005;82:2152-2157

17. Grarup N, Sandholt CH, Hansen, T and Pedersen O. Genetic Susceptibility to Type 2 Diabetes and Obesity: from Genome-wide Association Studies to Rare Variants and beyond. Diabetologia. 2014;57:1528-1541.

18. Barak YM, Nelson C, Ong ES, et al. PPAR $\gamma$ is required for placental, cardiac, and adipose tissue development. Molecular Cell. 1999;4(4):585-595

19. Lehrke M and Lazar MA. The many faces of PPAR $\gamma$. Cell. 2005;123(6):993-999.

20. Saxena R, Voight BF, Lyssenko V, et al. 2007. Genome-wide association analysis identifies loci for type 2 diabetes and triglyceride levels. Science. 2007;316:1331-1336.

21. Scott LJ, Mohlke KL, Bonnycastle LL, et al. A genome-wide association study of type 2 diabetes in Finns detects multiple susceptibility variants. Science. 2007 316(5829):1341-1345.

22. Steinthorsdottir V, Thorleifsson G, Reynisdottir I, et al. A variant in CDKAL1 influences insulin response and risk of type 2 diabetes. Nat Genet. 2007;39:770-775.

23. Hara M, Higaki Y, Taguchi N, et al. Effect of the PPARG2 Pro12Ala polymorphism and clinical risk factors for diabetes mellitus on $\mathrm{HbAlc}$ in the Japanese general population. J Epidemiol 2012;22:523-31.

24. Mori H, Ikegami H, Kawaguchi Y, et al. The Pro12 $\rightarrow$ Ala substitution in PPAR- $\square$ is associated with resistance to development of diabetes in the general population: possible involvement in impairment of insulin secretion in individuals with type 2 diabetes. Diabetes. 2001;50:891-894.

25. Meshkani R, Taghikhani M, Larijani B, et al. Pro12Ala polymorphism of the peroxisome proliferator-activated receptor- $\gamma 2$ (PPAR $\gamma-2$ ) gene is associated with greater insulin sensitivity and decreased risk of type 2 diabetes in an Iranian population. Clinical Chemistry and Laboratory Medicine. 2007;45(4):477-482. 26. Wang X, Liu J, Ouyang Y, et al. The Association between the Pro12Ala Variant in the
PPAR 2 Gene and Type 2 Diabetes Mellitus and Obesity in a Chinese Population. PLoS PPAR $\gamma 2$ Gene and Type 2 D

27. Barroso I, Gurnell M, Crowley VEF, et al. Dominant negative mutations in human PPAR $\square$ associated with severe insulin resistance, diabetes mellitus and hypertension. Nature. 1999;402(6764):880-883.

28. Evans D, de Heer J, Hagemann C, et al. Association between the P12A and c1431t polymorphisms in the peroxisome proliferator activated receptor $\gamma(\mathrm{PPAR} \gamma)$ gene and type 2 diabetes. Experimentaland Clinical Endocrinology and Diabetes. 2001;109(3):151-154.

29. Herder C, Rathmann W, Strassburger K, et al. Variants of the PPARG, IGF2BP2, CDKAL1, HHEX, and TCF7L2 genes confer risk of type 2 diabetes independently of BMI in the German KORA studies. Hormone and Metabolic Research. 2008;40(10):722726.

30. Majithiaa AR, Flannicka J, Shahiniana P, et al. Rare variants in PPARG with decreased activity in adipocyte differentiation are associated with increased risk of type 2 diabetes. PNAivity in adipocyte differentiation a

31. Bouassida KZ, Chouchane L, Jellouli K, et al. The peroxisome proliterator activated receptory2 (PPAR $\gamma 2$ ) Pro12Ala variant: lack of association with type 2 diabetes in obese and non obese Tunisian patients. Diabetes and Metabolism 2005;31(2):119-123.

32. Malecki MT, Frey J, Klupa T, et al. The Pro12Ala polymorphism of PPAR $\gamma 2$ gene and susceptibility to type 2 diabetes mellitus in a Polish population, mDiabetes Research and Clinical Practice, 2003;62(2):105-111.

33. Mato EPM, Pokam-Fosso PE, Atogho-Tiedeu B, et al. The Pro12Ala polymorphism in the PPAR- $\gamma 2$ gene is not associated to obesity and type 2 diabetes mellitus in a Cameroonian population. BMC Obes. 2016;3:26.

34. Al-Naemi AH, Ahmad AJ. Is the rs1801282 (G/C) Polymorphism of PPAR Gamma Gene Associated with T2DM in Iraqi People? Open Access Maced J Med Sci. 2021;6(3):447-55.

35. Hashemian L, Sarhangi N, Afshari M, et al. The role of the PPARG (Pro12Ala) common genetic variant on type 2 diabetes mellitus risk. Journal of Diabetes \& Metabolic Disorders. 2021; doi:10.1007/s40200-021-00872-6

36. Kang ES, Park SY, Kim HJ, Kim, et al. Effects of Pro12Ala polymorphism of peroxisome proliferator-activated receptor $\gamma 2$ gene on rosiglitazone response in type 2 diabetes. Clin Pharmacol Ther. 2005;78:202-208

37. Billings LK, Florez JC. The genetics of type 2 diabetes: what have we learned from GWAS? Ann N Y Acad Sci. 2010;1212:59-77.

38. Meybodi HRA, Hasanzad M and Larijani B. Path to personalized medicine for type 2 diabetes mellitus: reality and hope. Acta Med Iran.2017; 55(3): 166-174.

39. Ye E, Yang H, Chen L, et al. Adiponectin and peroxisome proliferator-activated receptor- $\gamma$ gene polymorphisms and gene-gene interactions with type 2 diabetes Life Sciences. 2014;98:55-59. 